\title{
The impact of family-centered care and meeting the need to learn how much of global anxiety in parents of children with urinary tract infection: a randomized clinical trial
}

\author{
Research Article
}

\author{
Hajar Sadeghi $^{1,2}$, Fatemeh Mehrabi ${ }^{3}$, Pouriya Darabiyan ${ }^{4}$, Yazdan Shabani ${ }^{*}$, Masoud Bahrami ${ }^{6}$ \\ 1. Master of Nursing, Department of Nursing, Faculty of Nursing, \\ Khomein University of Medical Sciences, Khomein, Iran. \\ 2. PhD Student in Nursing, Student Research Committee, \\ University of Social Welfare and Rehabilitation Sciences, Tehran, Iran. \\ 3. Master of Nursing, Faculty of Nursing, Arak University of Medical Sciences, Arak, Iran. \\ 4. Student Research Committee, Ahvaz Jundishapour University of Medical Sciences, Ahvaz, Iran. \\ 5. Medical Student, Student Research Committee, Arak University of Medical Sciences, Arak \\ 6. MSc Epidemiology, Arak University of Medical Sciences, Arak, Iran
}

\begin{abstract}
Backgrounds and Objectives: About 30\% of children hospitalized at least once during childhood, and about 5 percent hospitalized several times. The family is the most important source to support child patients, so the family centered care is necessary. One of the main sources of stress and anxiety for the family is the crisis by the hospitalization of ill children. Attention to the needs of mothers and reducing the anxiety from hospitalization is so important. The purpose of the study was to investigate the effects of family-centered care and meeting the need to learn how much of global anxiety in parents of hospitalized children. Materials and Methods: In the present Randomized clinical trial study, 70 parents of children suffering from UTI randomly divided in two groups: control (35) and intervention groups (35). Family-centered care was done by researcher and participating mothers. Control group received normal care. The data gathering tool was a three-part questionnaire: personal characteristics, Krastinzdottir questionnaire and Spiel Berger's questionnaire. Information were analyzed by using of SPSS software and chi-squared and t test. Results: The result of this study showed that the anxiety of the both group are the same and both of them are at the midrange. Range of meet information need in intervention and control group had statistically significant differences $(p<0.435)$. Conclusions: The family-centered care is effective at range of meet information needs of hospitalized children parent's and increase their satisfaction.
\end{abstract}

Keywords: Parent, Family Centered Nursing, Hospitalized Children; anxiety, Urinary Tract Infection .

\section{Background}

About $30 \%$ of children hospitalized at least once during childhood, and about 5 percent hospitalized several times. Necessities to meet the needs of children in hospital, Parents often are with children and cooperate in child care (1). Child is milestone of nurses communicate with parents means Childhood is the first relationship between parents and nurses. When the child is hospitalized due to severe illness, Mother needs more guidance with compassionate understanding because of responsibility of child care. The effect of parent in children is very important, so it's not possible to provide high-quality care alone, because parent's recognition of children is more than nurses. Education of parents and their partnership during hospitalization is necessary especially in Discharge of hospital. (2). Their

\footnotetext{
*Corresponding Author:

Yazdan Shabani,

Arak, Basij Square,

Arak University of Medical Sciences,

Arak, IR Iran.

E-mail: yazdansh74@gmail.com
}

most important needs is knowledge of treatment plan and answer honestly to parent's questions. Lack of information about the disease in addition to causing anxiety and abnormal behavior of parents (especially mothers) could result in be relapse and even readmission of children (3). The family is primary source for support to child patients, so family centered care is necessary to reach the target integrity, family unity of child patient and exclusive child care. The family centered case is an innovative approach to health care and it's important because united patient, health care providers and families (4). To achieve the optimal outcome, patients must be linked between Patients, family members, doctors, nurses and all care team members(5). So the family centered care is necessary (2). Lack of attention to the needs of parents from the nurses causing impaired communication between nurses and parents(6). One of the main sources of stress and anxiety for the family is the crisis by the hospitalization and ill children $(3,7)$. This crisis entered a severe stress to parents. Makes them different from normal position and to be anxious theme (8). The anxiety of parents on child development also affects the growth stages (9). 
According to close relationship of nurses with mothers of hospitalized children, Nurses can play an important role in reducing the stress and discomfort of hospitalized children mother's (8). Parents suffering from anxiety and depression can combine with loss of sense of responsibility to care, education and nutrition of children $(10,11)$. Parents are the most important people in the child protection system so reduce parental anxiety is important. Hashemzadeh et al study's (2007) showed that Urinary Tract Infection (UTI) is important causes of children hospitalization after infancy(12). UTI is a clinical condition that can affect urethra and bladder, ureters, pelvis, calyx and renal. The peak prevalence of UTI is in children between 2-6 years that they don't have structural abnormalities.UTI is 10 to 30 fold higher risk in female than male except infancy(5). Approximately $5 \%$ of girls and 1 percent of boys up to age 11 are diagnosed with a UTI (13). In $80 \%$ of cases, infection is E. coli and other gram-negative organisms, which it's common in around the anus and perineum. So it's needed proper and exact parental care that they are responsible for cleaning and caring for children(5). In addition to the importance of the needs of children in the hospital, attention to the needs of mothers is important too(14). Also parents needs to calm for providing adequate care and support of their children's $(3,15)$. Therefore, assess the information needs of families and decrease their anxiety is important.

\section{Objectives}

Effect of family centered care and meet the information needs of families and parent's anxiety was not observed after searching the available sources of study. Therefore, according to the new theory of nursing that is called as care essence of nursing and have seen impressive effect of family participation in the care and treatment, so this study was done to investigate the above mentioned components on children with UTI.

\section{Materials and Methods:}

In the present Randomized clinical trial study, 70 parents of children suffering from UTI randomly divided in two groups: control (35) and intervention groups (35). The study population was parents of children with UTI hospitalized in Amir Kabir Hospital in Arak. Both control and intervention groups were matched to Demographic characteristics. Standard deviation was 0.33 and mean difference was 0.18 (mean in interventional was 0.7 and in control was 0.52 ). 35 persons were in both control and interventional group. The data gathering tool was a three-part questionnaire. The first part of personal characteristics including age, sex, birth order, and question related parents include age, number of children, marital status, education, occupation, hospitalization of other family members, the insurance status and location. The second part of the questionnaire was parents need to obtain information consists of eleven phrase that used the needs of parents of children questionnaire from Karimi et al study (2008). It is retrieved from Krastinzdottir questionnaire. Questionnaire with 36 items is consisted of six areas of parent's needs including: needs to support and guidance, consultation, mutual confidence, obtaining information, comfort, convenience, communicating, and needs related to spouse and other family members. The phrase of this questionnaire was based on a three point Likert (never, somewhat, and fully). Questions were in order scored from 0 to 2, and the total score is obtained from the sum of the scores from eleven phrase. Cronbach's alpha coefficient for this tool is 0.867. The third part is Spiel Berger's questionnaire, which evaluated reliability and validity by Mahram et al in 1996.

The reliability of obvious anxiety was obtained 0.91 and for latent anxiety obtained 0.90. This questionnaire include 20 question for obvious anxiety which is based on the Likert scale with a score of 4 options (very low, low, high, and very high). For latent anxiety 20 question with Likert scale and 4 option (never, sometimes, often, and always). The 4 score in each statement indicating the highest level of anxiety and one score indicate lack of anxiety. Inclusion criteria are only Children 1 to 3 years; To be suffering from UTI; Career is the mother only; Mother has literacy to reading and writing and Exclusion criteria is Children with a history of hospitalization. Care for the control group done routinely. For interventional group obtained family centered care by researcher and participating mothers. Participation includes nutrition, change of clothes and diapers, axillaries temperature, Control adsorption and desorption, cleaning the child, Change sheets and give drug. The questionnaire was completed by both groups on admission and discharge. Finally, information was analyzed by descriptive statistic (frequency, mean and standard deviation) and analytic statistic (independent $t$ and paired $t$ test) by using of SPSS software, version 13.

\section{Results:}

In this study, $52.9 \%$ of participants were male, $47.1 \%$ of participants had a history of hospitalization, $4 \%$ of the parents of the participants had a history of hospitalization, $88.6 \%$ were married, $10 \%$ divorced and 1.4 percent of husbands had died. The education level of 2.9 percent were illiterate, $20 \%$ cycles, primary $25.7 \%, 42.9 \%$ Diploma and $8.6 \%$ had academic education. 7.1 percent of participants were employee, $2.9 \%$ employment and 90\% were housewives. 88.6 percent had insurance and 75.7 percent were native.

According to table (1) obvious anxiety before intervention in intervention group were 47.08 and in control group were 52.38. Also latent anxiety in intervention group were 45.9 and in control group were 45.1. After intervention at time of discharge, obvious anxiety in intervention group were 45.1, in control 
group were 48.8, also latent anxiety in intervention group were 46.3 and in control group were 45.1 . Comparing two groups with t-paired showed that intervention doesn't affect the obvious and latent anxiety, because there's no difference between before and after, that it's can because of low sample size.

The results in table (2) showed that mean of meet information need in intervention group at before were $0.71 \pm 0.32$, after intervention were $1.7 \pm 0.29$, so not seen significant difference with t-test $(\mathrm{p}<0.435)$.

According to table 3 and 4 most meet to information need of parents of children were this phrase: "anything done to my child, explained it for me" that in control group were $0.83 \pm 0.77$ and in intervention group were $2.35 \pm 0.58$. After that in order were this phrases: "I receive written information in plain language about my child" (for example: description of the disease, the need for hospitalization, diagnostic terms, drug names and trials...) that in control group were $0.72 \pm 0.65$ and in intervention group were $1.85 \pm 0.35$, "I received accurate information about the child and disease outcomes" that in control group were $0.77 \pm 0.63$ and in intervention group were $1.82 \pm 0.38$.

\section{Discussion}

The results of this study showed that parents of hospitalized children with urinary tract infections will always experience some degree of anxiety. This rate were moderate in the beginning of hospitalization, this results consist with Shirley, Elaine, Needle, Scrimin, Chahal,Wray, Pekcanlarakay, laine, Hemmati, Ghasemi and Sanjari. It is a sign of anxiety for parents (16-25).

In this study anxiety has not changed in both control and intervention groups, and it's so in moderate level. In this regard, several studies have been conducted that can be pointed to line, Zuwala and Vita Carvalh. All this studies showed that the anxiety of parents is reduced with given adequate and understandable information to them $(19,26)$. In this study anxiety reduced, but it is not a significant level. That can explain by environment, barriers to parent participation, understanding parents and low sample size.

According to the Nichols study, clinical setting can have a significant impact on process of family centered care and parent $\operatorname{anxiety}(27)$. Also Hopia assume nurses support and other staff depends on good communication with parents (28). Mack Kill et al assumed lack of time and shortage of staff is barriers to parent participation, which is consistent with Vasli's study(29). Kyritsi et al found that 98 to 100 percent of parents need to take the following information: prognosis of them children, the effects of disease and treatment on growth and development of infants, preparing for discharge, reason of anything that is done for children, consent information about their child's health, knowledge a s soon as the results of experiments on children, and if need be received required information from social worker for financial problems (3).

Jackson's et al study showed Quality of care and give information to them is important, also this study revealed that providing care at an optimum level and proper social and cultural environment can give Selfconfidence to parents in the parent's role(30). It must be understood according to a Beal and Quinn's study, the main task of nurses is "Confidence and reassurance, support, care, to provide information for understanding and provide comfort for parents"(31). Karimi results showed that the parents think these needs are met partially (1). Aein also in their study mentioned this mother's needs: "The need to respond to questions" and "the need for useful and timely information", it also noted mothers need to know nurses what nurses have to solve child's problem.

Ignoring the needs causes than mothers feel that nurses are indifferent to the problem of child, as a result causes the contrast between the mother and nurse (14).

In this regard Kathleen's study showed Mothers knowing receive of informational and communication support by nurses as a contributing factors in the adaptation of parents, they also encourages familycentered care whit provide honest answers to their questions(32). Mok's et al study was conducted in Hong Kong, this study examined the effect of family-centered care on meeting the information needs and showed that most parents had received information communication support(33). Mayumi et al study in Tokyo showed that Important factors in the nurse's role as a supplier of support for family members is response to family members problems, helping family members to express their feelings (emotional support) and lead to stable position(34). Akbarbegloo et al also showed that giving information to parents couses they have a snse of control and power over their position and participate more in the care of their children (35). It seems that according to the results of these findings to suggest family-centered care can meet the needs of parents of hospitalized children in get information scope, finally they more involved in care.

Care is the essence of nursing. Nurses must improve their capability to participate with patient's families, which this makes care, to be successful. According to results of this study, parent's participation based on family centered model lead children to significantly improve. Moreover, the implementation of family-centered model has helped parents to reduce anxiety and improve cognitive science. Therefore, nurses due to their key role in care, the time required to communicate and based on their knowledge and experience can contribute parents in the care of their own children and play an important role in improving child and their satisfaction. 
According to research finding, it's recommended that retraining courses to be held for nurses about hospitalized children parent's needs, it's importance in recovery, and increase their satisfaction, to be more the vision and practice of nurses and parental participation in this field. Also meet the needs and facilities required for implementation of family-centered care in hospitals should be considered by authorities.

\section{Acknowledgments}

This article is result of the research project at Arak University of Medical Sciences With registration number 1204, ethics Code 93-169-17 and clinical trial code to No. IRCT2016010625843N2. We would like to thank the Deputy Research for approval and financial support of this study, staffs of Amir Kabir Hospital Arak and Parents of hospitalized children.

\section{Conflicts of Interest} declare.

The authors have no conflicts of interest to

\section{Financial Disclosure} interests.

The authors declare that they have no competing

\section{Funding/Support}

This project was funded by the Research Deputy of Arak University of Medical Sciences and Health care, Arak, IR Iran and specified as the grant number: 1204.

\section{References:}

1. Karimi R, Daneshvar Z, Sadat Hoseini A, Mehran A, Shiri M. Perceptions of parents and nurses on needs of hospitalized. hayat. 2008;14(1):31-9.

2. Zeinali Z, Mirhaghjou N, Mirzaei M, Alhani F, Kazemnezhad Leili E, Dehghani M. The effect of family centered care on meeting parental information needs of hospitalized children. Holistic Nursing and Midwifery. 2012;22(67):30-7.

3. Kyritsi H, Matziou V, Perdikaris P, Evagelou H. Parents needs during their child's hospitalization. ICUS Nurse Web J. 2015;23(3).

4. Pettoello-Mantovani M, Campanozzi A, Maiuri L, Giardino I. Family-oriented and family-centered care in pediatrics. Italian journal of pediatrics. 2009;35(1):12.

5. Wong DL, Wilson D. Whaley and wong's nursing care of infants and children 5th, editor. philadelphia: mosby; 1991.

6. Marlow DR, Redding BA. Marlow's Textbook of Pediatric Nursing 6th, editor. London, United Kingdom: Elsevier Health Sciences; 2013.

7. Ygge BM, Lindholm C, Arnetz J. Hospital staff perceptions of parental involvement in paediatric hospital care. Journal of advanced nursing. 2006;53 (5):534-42.

8. Mohammadi R, seyedJavadi M, Mazaheri E, editors. Maternal anxiety in hospitalized infants ,Twenty-fourth International Conferenceofchildrenand the secondNational Conference onPediatric Nursing2012; tehran.

9. James S, Ashwill J. Nursing Care of Children, Principles and Practice. 3rd, editor. USA: USA Elsevier; 2007.

10. Coyne I. Disruption of parent participation: nurses' strategies to manage parents on children's wards. Journal of clinical nursing. 2008;17(23):3150-8.

11. Minkovitz CS, Strobino D, Scharfstein D, Hou W, Miller T, Mistry KB, et al. Maternal depressive symptoms and children's receipt of health care in the first 3 years of life. Pediatrics. 2005;115(2):30614.

12. Hashim A, Heidari F. Investigate the causes symptoms in children under 5 years admitted to hospital pediatric wards of Ghaem Mashhad. Journal of Sabzevar School of Medical Sciences. 1384;12(4):42-7.

13. Nelson. Fundamentals of Pediatrics Nelson: thran venerable; 2011.

14. Aein F, Mohamadi E, Kazemnejad A. Marginating the interpersonal relationship: Nursesana parents experiences of communication in pediatric wards. IJNR. 2008;3(9):71-83.

15. Papastavrou E, Efstathiou G, Charalambous A. Nurses' and patients' perceptions of caring behaviours: quantitative systematic review of comparative studies. Journal of advanced nursing. 2011;67(6):1191-205.

16. Chahal N, Clarizia NA, McCrindle BW, Boydell KM, Obadia M, Manlhiot C, et al. Parental anxiety associated with Kawasaki disease in previously healthy children. Journal of pediatric health care : official publication of National Association of Pediatric Nurse Associates \& Practitioners. 2010;24 (4):250-7.

17. Ghasmee F, Khanjaree S, Vasefi M, Haghani H. Study Of Maternal Anxiety After Hospitalization Of Their Children, Before And After His/Her Discharge. IJNR. 2001;13(27):30-4.

18. Hemmati M, editor Study Of Anxiety Level In The Parents Of Hospitalized Children During The Reception And Discharge In Imam Khomeini Of Urmia.(Dissertation). Tabriz University; 1996; Tabriz.

19. Laine L, Shulman RJ, Bartholomew K, Gardner P, Reed T, Cole S. An educational booklet diminishes anxiety in parents whose children receive total parenteral nutrition. American journal of diseases of children (1960). 1989;143(3):374-7.

20. Needle JS, O'Riordan M, Smith PG. Parental anxiety and medical comprehension within $24 \mathrm{hrs}$ 
of a child's admission to the pediatric intensive care unit*. Pediatric critical care medicine : a journal of the Society of Critical Care Medicine and the World Federation of Pediatric Intensive and Critical Care Societies. 2009;10(6):668-74; quiz 74.

21. Pekcanlar Akay A, Hiz Kurul S, Ozek H, Cengizhan S, Emiroglu N, Ellidokuz H. Maternal reactions to a child with epilepsy: Depression, anxiety, parental attitudes and family functions. Epilepsy research. 2011;95(3):213-20.

22. Scrimin S, Haynes M, Altoe G, Bornstein MH, Axia G. Anxiety and stress in mothers and fathers in the $24 \mathrm{~h}$ after their child's surgery. Child: care, health and development. 2009;35(2):227-33.

23. Shirley PJ, Thompson N, Kenward M, Johnston G. Parental anxiety before elective surgery in children. A British perspective. Anaesthesia. 1998;53(10):956 -9 .

24. Wirrell E, Turner T. Parental anxiety and family disruption following a first febrile seizure in childhood. Paediatrics \& child health. 2001;6 (3):139-43.

25. Wray J, Lee K, Dearmun N, Franck L. Parental anxiety and stress during children's hospitalisation: the StayClose study. Journal of child health care : for professionals working with children in the hospital and community. 2011;15(3):163-74.

26. Carvalho AE, Linhares MB, Padovani FH, Martinez FE. Anxiety and depression in mothers of preterm infants and psychological intervention during hospitalization in neonatal ICU. The Spanish journal of psychology. 2009;12(1):161-70.

27. Nichols A. The impact of the clinical environmenton family centred care in the neonatalunit: A qualitative investigation. Journal of Neonatal Nursing 2014;20:230-35.

28. Hopia H, Tomlinson PS, Paavilainen E, AstedtKurki P. Child in hospital: family experiences and expectations of how nurses can promote family health. Journal of clinical nursing. 2005;14(2):21222.

29. Vasli P, Salsali M, Tatarpoor P. Perspectives of Nurses on Barriers of Parental Participation in Pediatric Care: A Qualitative Study. Jpn J Nurs Sci. 2012;18(3):22-32.

30. Jackson K, Ternestedt BM, Magnuson A, Schollin J. Quality of care of the preterm infant--the parent and nurse perspective. Acta paediatrica (Oslo, Norway : 1992). 2006;95(1):29-37.

31. Beal JA, Quinn M. The nurse practitioner role in the NICU as perceived by parents. MCN The American journal of maternal child nursing. 2002;27(3):183-8.

32. Meert KL, Schim SM, Briller SH. Parental bereavement needs in the pediatric intensive care unit: review of available measures. Journal of palliative medicine. 2011;14(8):951-64.

33. Mok E, Leung SF. Nurses as providers of support for mothers of premature infants. Journal of clinical nursing. 2006;15(6):726-34.

34. Mayumi M, Reiko N, Yoko K. Nurses perception of their relationalbehavior with family members ofhospitalized patients: Survey of nurseswho work at national hospital organizations in Tohoku district. Journalof the Faculty of Nursing. 2006;8:1-12.

35. Akbarbegloo $M$, Valizadeh L, Asadollahi $M$. Mothers and Nurses View about importance and level ofnursing supports of neonates family hospitalized in NICU. Journal of intensive care. 2009;2(2):71-4.

Table 1: Compares the level of anxiety in the intervention and control groups before and after intervention with Use of paired t-test

\begin{tabular}{|c|c|c|c|c|c|}
\hline \multicolumn{2}{|c|}{ Variable } & Control group & P. value & Intervention & P. value \\
\hline \multirow{2}{*}{$\begin{array}{l}\text { Clear } \\
\text { Anxiety }\end{array}$} & pre & 47.1 & \multirow[t]{2}{*}{0.007} & 52.4 & \multirow[t]{2}{*}{0.021} \\
\hline & post & 45.1 & & 48.8 & \\
\hline \multirow{2}{*}{$\begin{array}{l}\text { Hidden } \\
\text { Anxiety }\end{array}$} & pre & 45.9 & \multirow[t]{2}{*}{0.332} & 45.1 & \multirow[t]{2}{*}{0.119} \\
\hline & post & 45.0 & & 46.3 & \\
\hline
\end{tabular}

Table 2: Comparison of the mean total parental Information level in both groups before and after the intervention with Use of paired t-test

\begin{tabular}{|c|c|c|c|c|c|}
\hline \multicolumn{2}{|c|}{ Variable } & Intervention group & P. value & Control group & P. value \\
\hline $\begin{array}{c}\text { Information } \\
\text { level }\end{array}$ & pre & $0.71 \pm 0.32$ & 0.603 & $0.59 \pm 0.19$ & 0.435 \\
\cline { 2 - 3 } & post & $1.7 \pm 0.28$ & & $0.83 \pm 0.23$ & \\
\hline
\end{tabular}


International Journal of Ayurvedic Medicine, 2019, 10(1), 68-74

Table 3: The information in question in the control group before and after intervention

\begin{tabular}{|c|c|c|c|c|c|}
\hline Items & & $\begin{array}{c}\text { Mean } \pm \\
\text { SD } \\
\end{array}$ & throughly & Somewhat & Ever \\
\hline \multirow[t]{2}{*}{ The staff I met. } & Pre & $0.69 \pm 0.62$ & $3(8.3)$ & 19(52.8) & (38.9)14 \\
\hline & Post & $0.94 \pm 0.47$ & $3(8.3)$ & $28(77.8)$ & 5(13.9) \\
\hline \multirow{2}{*}{$\begin{array}{l}\text { I was familiar with the physical } \\
\text { environment. }\end{array}$} & Pre & $0.83 \pm 0.73$ & $7(19.4)$ & $16(44.4)$ & 13(36.1) \\
\hline & Post & $1.22 \pm 0.48$ & $9(25)$ & $26(72.2)$ & $1(2.8)$ \\
\hline \multirow[t]{2}{*}{ I met with existing equipment. } & Pre & $0.77 \pm 0.68$ & 5(13.9) & $18(50)$ & $13(36.1)$ \\
\hline & Post & $1.08 \pm 0.6$ & $8(22.2)$ & $23(63.9)$ & 5(13.9) \\
\hline \multirow{2}{*}{$\begin{array}{l}\text { Was familiar with the laws and } \\
\text { regulations of the sector. }\end{array}$} & Pre & $0.83 \pm 0.65$ & 5(13.9) & $20(55.6)$ & 11(30.6) \\
\hline & Post & $1.08 \pm 0.64$ & 9(25) & 21(58.3) & 6(16.7) \\
\hline \multirow{2}{*}{$\begin{array}{l}\text { Anything done to my child, } \\
\text { because I explained it. }\end{array}$} & Pre & $0.63 \pm 0.68$ & $4(11.1)$ & 15(41.7) & 17(47.2) \\
\hline & Post & $0.83 \pm 0.77$ & $8(22.2)$ & 14(38.9) & $14(38.9)$ \\
\hline \multirow{2}{*}{$\begin{array}{l}\text { The results of testing, treatment } \\
\text { and nursing care for my child will } \\
\text { be informed. }\end{array}$} & Pre & $0.63 \pm 0.59$ & $2(5.6)$ & 19(52.8) & $15(41.7)$ \\
\hline & Post & $0.69 \pm 0.52$ & $1(2.8)$ & $23(63.9)$ & $12(33.3)$ \\
\hline \multirow{2}{*}{$\begin{array}{l}\text { The impact of diseases and their } \\
\text { treatment have received training } \\
\text { on child development. }\end{array}$} & Pre & $0.33 \pm 0.47$ & $0(0)$ & $12(33.3)$ & $24(66.7)$ \\
\hline & Post & $0.55 \pm 0.5$ & $0(0)$ & $20(55.6)$ & $16(44.4)$ \\
\hline $\begin{array}{l}\text { Written in plain language } \\
\text { information about the child } \\
\text { received. (For example: the } \\
\text { description of the disease the need } \\
\text { for hospitalization, drug name } \\
\text { and trials...) }\end{array}$ & Pre & $0.41 \pm 0.55$ & $1(2.8)$ & $13(36.1)$ & $22(66.1)$ \\
\hline \multirow{3}{*}{$\begin{array}{l}\text { I received the correct information } \\
\text { about the situation of children } \\
\text { and disease outcomes. }\end{array}$} & Post & $0.72 \pm 0.65$ & $4(11.1)$ & $18(50)$ & $14(38.9)$ \\
\hline & Pre & $0.58 \pm 0.55$ & $1(2.8)$ & 19(52.8) & $16(44.4)$ \\
\hline & Post & $0.77 \pm 0.63$ & $4(11.1)$ & $20(55.6)$ & $12(33.3)$ \\
\hline \multirow{2}{*}{$\begin{array}{l}\text { Since the beginning of the } \\
\text { reception, preparation and } \\
\text { guidance about registering my } \\
\text { child. }\end{array}$} & Pre & $0.61 \pm 0.68$ & $4(11.1)$ & $14(38.9)$ & 18(50) \\
\hline & post & $0.86 \pm 0.68$ & $6(16.7)$ & $19(52.8)$ & $11(30.6)$ \\
\hline \multirow{2}{*}{$\begin{array}{l}\text { If necessary, the social worker } \\
\text { about sources of financial support } \\
\text { to solve the problems created } \\
\text { following the hospitalization of } \\
\text { my child has received the } \\
\text { necessary information. }\end{array}$} & Pre & $0.22 \pm 0.42$ & $0(0)$ & $8(22.2)$ & $28(77.8)$ \\
\hline & Post & $0.44 \pm 0.55$ & $0(0)$ & $15(41.7)$ & $21(58.3)$ \\
\hline
\end{tabular}


HajarSadeghil et.al., The impact of family-centered care and meeting the need to learn how much of global anxiety

Table 4: Average data by question in the intervention group before and after intervention

\begin{tabular}{|c|c|c|c|c|c|}
\hline Items & & $\begin{array}{l}\text { Mean } \pm \\
\text { SD }\end{array}$ & throughly & Somewhat & Ever \\
\hline \multirow[t]{2}{*}{ The staff I met. } & Pre & $0.88 \pm 0.47$ & $2(5.9)$ & $26(76.5)$ & $6(17.6)$ \\
\hline & Post & $1.58 \pm 0.49$ & $20(58.8)$ & $14(41.2)$ & $\overline{0(0)}$ \\
\hline \multirow{2}{*}{$\begin{array}{l}\text { I was familiar with the physical } \\
\text { environment. }\end{array}$} & Pre & $0.94 \pm 0.54$ & $4(11.8)$ & 24(70.6) & $6(17.6)$ \\
\hline & Post & $1.5 \pm 0.56$ & $18(52.9)$ & $15(44.1)$ & $1(2.9)$ \\
\hline \multirow[t]{2}{*}{ I met with existing equipment. } & Pre & $1.11 \pm 0.59$ & $6(17.6)$ & 25(73.5) & $3(8.8)$ \\
\hline & Post & $1.65 \pm 0.54$ & $23(67.4)$ & $10(29.4)$ & $1(2.9)$ \\
\hline \multirow{2}{*}{$\begin{array}{l}\text { Was familiar with the laws and } \\
\text { regulations of the sector. }\end{array}$} & Pre & $1.21 \pm 0.53$ & $7(20.6)$ & 24(70.6) & $3(8.8)$ \\
\hline & Post & $1.74 \pm 0.51$ & $26(76.5)$ & $7(20.6)$ & $1(2.9)$ \\
\hline \multirow{2}{*}{$\begin{array}{l}\text { Anything done to my child, } \\
\text { because I explained it. }\end{array}$} & Pre & $0.97 \pm 0.79$ & $\overline{8(24.5)}$ & $16(47.1)$ & $10(29.4)$ \\
\hline & Post & $2.35 \pm 0.58$ & $29(85.3)$ & $4(11.8)$ & $1(2.9)$ \\
\hline \multirow{2}{*}{$\begin{array}{l}\text { The results of testing, treatment } \\
\text { and nursing care for my child will } \\
\text { be informed. }\end{array}$} & Pre & $0.52 \pm 0.66$ & $3(8.8)$ & $12(35.3)$ & 19(55.9) \\
\hline & Post & $1.79 \pm 0.53$ & $29(85.3)$ & $3(8.8)$ & $2(5.9)$ \\
\hline \multirow{2}{*}{$\begin{array}{c}\text { The impact of diseases and their } \\
\text { treatment have received training } \\
\text { on child development. }\end{array}$} & Pre & $\overline{0.47 \pm 0.7}$ & $4(11.8)$ & $\overline{8(33.5)}$ & $22(64.7)$ \\
\hline & Post & $1.82 \pm 0.45$ & $29(85.3)$ & $4(11.8)$ & $1(2.9)$ \\
\hline $\begin{array}{l}\text { Written in plain language } \\
\text { information about the child } \\
\text { received. (For example: the } \\
\text { description of the disease the need } \\
\text { for hospitalization, drug name } \\
\text { and trials...) }\end{array}$ & Pre & $0.47 \pm 0.66$ & $3(8.8)$ & $10(29.4)$ & $21(61.8)$ \\
\hline \multirow{3}{*}{$\begin{array}{l}\text { I received the correct information } \\
\text { about the situation of children } \\
\text { and disease outcomes. }\end{array}$} & Post & $1.85 \pm 0.35$ & $29(85.3)$ & $5(14.7)$ & $\overline{0(0)}$ \\
\hline & Pre & $0.7 \pm 0.62$ & $3(8.8)$ & $18(52.9)$ & $13(38.2)$ \\
\hline & Post & $1.82 \pm 0.38$ & $28(82.4)$ & $6(17.6)$ & $\overline{0(0)}$ \\
\hline \multirow{2}{*}{$\begin{array}{l}\text { Since the beginning of the } \\
\text { reception, preparation and } \\
\text { guidance about registering my } \\
\text { child. }\end{array}$} & Pre & $0.52 \pm 0.56$ & $1(2.9)$ & $16(47.1)$ & $17(50)$ \\
\hline & post & $1.38 \pm 0.6$ & $15(44.1)$ & $17(50)$ & $2(5.9)$ \\
\hline \multirow{2}{*}{$\begin{array}{l}\text { If necessary, the social worker } \\
\text { about sources of financial support } \\
\text { to solve the problems created } \\
\text { following the hospitalization of my } \\
\text { child has received the necessary } \\
\text { information. }\end{array}$} & Pre & $0.08 \pm 0.28$ & $\overline{0(0)}$ & $3(8.8)$ & $31(91.2)$ \\
\hline & Post & $1.27 \pm 0.66$ & $13(38.2)$ & $17(50)$ & $4(11.8)$ \\
\hline
\end{tabular}

